\section{Hepatite C crônica: estudo de marcadores histológicos e imuno-histoquímicos do vírus e da resposta imune dos pacientes}

Centrado na hepatite $C$, o presente estudo visou a uma análise crítica dos critérios que compõem as propostas atuais para uma nova classificação histológica das hepatites crônicas, especialmente quanto à distribuição e interrelações entre as variáveis. A imuno-fenotipagem de linfócitos foi usada principalmente para verificar aspectos comuns ou peculiares das principais lesões histológicas na hepatite C. Estas lesões foram, ainda, relacionadas à replicação viral, avaliada pela pesquisa de RNAVHC mediante PCR em amostra de soro e à distribuição tecidual de antígeno core do VHC marcado por um novo antissoro antipeptídeos sintéticos de seus 50 amino-ácidos iniciais, em busca de evidências de eventuais mecanismos patogenéticos dos principais fenômenos morfológicos.

A casuística foi constituída por 180 biópsias hepáticas de pacientes soro-positivos para anticorpos anti-VHC sem evidências de imunosupressão ou de doenças associadas, selecionados apenas com base na disponibilidade de amostra de tecido adequadamente processado para os estudos histológicos e imuno-histoquímicos.

Em cada biópsia foram semiquantificadas 9 variáveis histológicas, indicativas do grau de alterações arquiteturais (estadiamento) e da atividade necro-inflamatória nos compartimentos portais, peri-portais e intralobulares.

Em todos os casos, foram também efetuadas pesquisas imuno-histoquímicas para o antígeno core do VHC, através de um novo antissoro de coelho Rb246 dirigido a epitopos imunodominantes das sequências dos primeiros 50 amino-ácidos da região core, usando-se como imunógeno em uma solução com peptídeos sintéticos. $\mathrm{O}$ anti-soro foi purificado mediante absorção com cortes de fígado co-infectado pelos VHB e VHD. Para garantia da especificidade do sinal, foram realizados bloqueios de

Recebido para publicação em 12/09/97.

\section{Chronic hepatitis C: study of histological and immunohistochemical markers of the virus and of patients' immune response}

Based on the model of hepatitis $C$, this study aimed at analysing the histological criteria included in the most important proposals for a new classification of chronic hepatitis. Special attention was devoted to the distribution and inter-relationship among the histological criteria of lesions, whose lymphocytes were immunophenotyped.

The topographical distribution of immunoreactivity to a novel polyclonal antibody directed to several synthetic peptides encompassing short epitopes of the immuno-dominant initial sequence of HCV core antigen was also assessed. Viral replication "status" was previously assessed through a RT-PCR for HCV-RNA. The inter-relationship among the data obtained by the several molecular and morphological approaches was studied, in the search for some useful data for a better understanding of the pathogenesis of HCV-related lesions.

The subject of this study was the group of 180 biopsies from patiens who searched for clinical assistance, all of them sero-positive for anti-HCV. All cases with immunosupression or associated illnesses were excluded. The selection was based only on the availability of representative tissue samples for histology and for immuno-histochemistry.

All biopsy specimens were submitted to a semi-quantitative analysis of 9 histological variables, related to the architectural disturbances ("staging") and to the necro-inflammatory activity of each compartment of the hepatic lobule, specifically the portal tract, the peri-portal region and the lobular parenchyma.

Each sample was also submitted to immunohistochemical assays for the HCV core antigen, through a novel rabbit antiserum directed to a cocktail of synthetic peptides encompassing immuno-dominant epitopes of the initial 50 aminoacid sequences of the core region.

The rabbit antiserum was purified through absorption with sections of frozen liver coinfected with HBV and HDV. In order to assure the specificity of the immunohistochemical 
possíveis interações proteicas e a amplificação foi obtida pelo sistema peroxidase-antiperoxidase.

As 40 amostras com máxima atividade inflamatória foram motivo de imuno-fenotipagem de linfócitos nas áreas de lesão, usando anticorpos monoclonais já disponíveis para a detecção de antígenos CD20 de linfócitos B, CD4 de linfócitos T-auxiliares, CD8 de linfócitos T citotóxicos e CD57, marcador de células "natural killer" (NK). Sua aplicação às amostras rotineiramente fixadas em formol e incluídas em parafina foi otimizada por métodos de "recuperação antigênica" mediante exposição ao calor em forno de micro-ondas ou panela de pressão. A amplificação dos sinais da imunofenotipagem foi obtida pelo sistema estreptavidina-biotina-peroxidase.

Os dados de PCR para RNA-VHC foram anotados a partir dos prontuários de 85 casos e foram relacionados aos demais critérios.

A análise histológica semi-quantitativa mostrou distribuição ampla de todos os "estádios": 15,55\% dos casos apresentavam distúrbios arquiteturais "leves", estando 40,00\% em "fases intermediárias" e $44,45 \%$ em transformação nodular ou com cirrose já instalada. Agregados ou folículos linfóides, vistos em $56,67 \%$ das amostras, mostraram-se intimamente ligados às lesões de ductos biliares, que foram discretas em $30,56 \%$ e moderadas/acentuadas em $30,00 \%$ dos casos.

Ainda que a "necrose em saca-bocados" tenha sido detectada em $89,44 \%$ das amostras, esteve restrita a "pequenos focos" em 38,89\% ou foi vista em quantidade moderada em 28,33\%.

Excetuando-se a "necrose focal", presente em 178 dos 180 casos, associações estatisticamente significantes foram demonstradas entre os diversos marcadores histológicos de "estadiamento" dos distúrbios arquiteturais e os indicadores de atividade necro-inflamatória portal, peri-portal ou lobular. A presença de índices elevados de inflamação nas fases avançadas da doença contrasta com os achados na hepatite $B$, sugerindo que, na hepatite $C$, haja um aumento progressivo na atividade viral (replicação e expressão) e na resposta linfocitária do paciente.

A análise semiquantitativa da distribuição dos principais sub-tipos de linfócitos em cada padrão de lesão hepática demonstrou marcantes diferenças entre os fenômenos portais e os peri- signal, the blockage of protein-protein interaction was performed, whereas the amplification of the reaction was achieved through the peroxidaseanti-peroxidase system.

Forty samples with outstanding inflammatory activity were submitted to lymphocytic subtyping, through commercially available monoclonal antibodies to CD20, a B-lineage lymphocyte marker, CD4 to T-helper-lymphocytes, CD8, to T-cell-cytotoxic sub-population and CD57 to "natural killer cells". Optimization of these immunophenotyping reactions in routinely formalin-fixed paraffin-embedded samples was achieved through heat-induced epitope retrieval methods under micro-wave oven or pressure cooker. The amplification of these reactions was performed by the streptavidin-biotin-peroxidase complex.

RT-PCR data for the (qualitative) detection of HCV-RNA was compiled from clinical charts from 85 patients and submitted to statistical analysis of relation to the histological and immunohistochemical variables.

The semi-quantitative histological analysis showed the several stages of disease widely represented: $15.55 \%$ were found in "early stages", $40.00 \%$ in "intermediate" and $44.45 \%$ in nodular transformation or already cirrhotic.

Lymphoid follicles/aggregates, seen in $56.67 \%$ of the samples, were intimately linked to biliary duct lesions, which were light in $30.56 \%$ and moderate/severe in $30.00 \%$ of the cases.

Although "piece-meal necrosis" was found in the $89.44 \%$ of the samples, it was restricted to small foci in $38.89 \%$ or in moderate amount in $28.33 \%$.

Except for "spotty necrosis", which was almost always present, highly significant statistic inter-relationships were demonstrated among "staging" and the histological markers of necroinflammatory activity, either in portal tracts, in peri-portal region or at lobular parenchyma. The marked prevalence of high inflammatory indexes in advanced stages was strongly different from the data showed in previous reports on Hepatitis $B$, and such histological pattern in Hepatitis C could be related to a progressive rise both in viral activity (replication and expression) and in the patient's lymphocytic response.

The semi-quantitative analysis of the distribution of major subtypes of lymphocytes in each pattern of hepatic lesion showed marked differences in the peri-portal versus portal 
portais:

Linfócitos T CD8+ predominaram nas áreas de "necrose peri-portal", enquanto os CD4+ foram o maior componente da inflamação nas regiões centrais dos espaços-porta.

Os folículos linfóides portais, ativação peculiar de linfócitos B CD20+, contiveram uma população relativamente grande de linfócitos $T$ CD4+. Este sinergismo também foi observado nas lesões do epitélio biliar, levantando a hipótese de que este fenômeno possa representar um aspecto do "sistema M.A.L.T. adquirido", até aqui não referido no fígado.

A necrose de hepatócitos no interior do lóbulo, seja "focal" ou "confluente", mostrou-se associada à presença de linfócitos $\mathrm{T}$, com alguma superioridade dos CD4+ sobre os CD8+.

Células NK CD57+ foram encontradas em pequena quantidade em todas as lesões estudadas, coerente com seu papel acessório à resposta linfóide. De outra parte, a notável imuno-reatividade para CD57 nos hepatócitos e ductos biliares lesados sugere a participação desta molécula como "marcador de ativação" de células-alvo para o infiltrado linfocítico em hepatite $\mathrm{C}$.

O "status de replicação viral" marcado pela positividade para RNA de VHC mediante PCR mostrou-se estatisticamente relacionado ao estadiamento das lesões hepáticas, mas não a qualquer das variáveis indicativas de atividade necro-inflamatória.

A detecção de epitopos imuno-dominantes do antígeno core foi confirmada como confiável em amostras fixadas em formol e incluídas em parafina. De modo similar aos poucos estudos relatando a identificação imuno-histoquímica do antígeno core do VHC, sessenta e dois casos $(34,44 \%)$ de nossas amostras de VHC mostraram-se positivas, não havendo imunoreatividade em nenhum dos 48 controles negativos. Ainda que menos sensível, a detecção do antígeno core esteve estatisticamente relacionada à detecção de RNA-VHC no soro dos pacientes, sugerindo sua utilidade como marcador indireto de replicação viral. A detecção do antígeno core mostrou-se também significativamente relacionada ao estadiamento histológico e ao grau de necrose peri-portal e lobular. Este achado pode indicar que a expressão de epitopos imuno-dominantes do antígeno core poderia atrair os linfócitos $\mathrm{T}$, lesions: CD8+ T lymphocytes were directly linked to "piece-meal necrosis", whereas the CD4+ T cells were the major component of the inflammation at the central interstitium of portal tracts. The lymphoid follicles, a peculiar CD20+ $B$-Iymphocyte activation in Hepatitis C, encompassed a rather large population of CD4+ $\mathrm{T}$ helper lymphocytes. This synergism was also marked at the biliary epithelial lesions, leading to a hypothesis that this phenomenon could represent a trend to the "acquired M.A.L.T." of the liver.

Intra-lobular parenchymal necrosis, either "spotty" or "confluent", was linked to T lymphocytes, with a slight superiority of CD4+ cells to those CD8+.

CD57+ "natural killer" cells were seen in small amount in each of the lesions studied herein, suggesting an accessory role for this sub-population. The remarkable CD57 immunostaining of the "suffering" hepatocytes and bile duct epithelial cells would suggest an hypothetical role of this molecule as a "marker of activation" for cells to be attacked the lymphocytic infiltrate in hepatitis $\mathrm{C}$.

The detection of immunodominant epitopes of the core antigen was confirmed reliable in routinely formalin-fixed paraffin-embedded samples.Similar to a small number of previous reports of $\mathrm{HCV}$ core antigen immunohistochemical detection, sixty-two cases (34.4\%) of our HCV samples were found positive, with no staining of any of the 48 negative controls. Although less sensitive, the core antigen immunostaining was statistically related to the PCR detection of serum HCV-RNA, suggesting it could be an indirect marker of viral replication. Moreover, core antigen immunohistochemical detection was found significantly associated to histological staging, as well as to the grade of peri-portal and lobular necrosis. This finding could hypothetically mean that the expression of immunodominant epitopes of the initial sequences of the HCV core antingen would attract the T-lymphocytes, targetting the focci for a necro-inflammatory activity. The lack of correlation of $\mathrm{HCV}$ core antigen detection in portal inflammation could be a hint for an autoimmune role in these lesions.

Furthermore, a "compartimentalized" study of the core antigen immuno-reactivity showed, in the liver parenchyma, a marked prevalence of the antigen in morphologically normal hepatocytes. Individually, this finding could suggest spotty 
marcando os alvos para os focos de atividade necro-inflamatória. A falta de correlação da detecção do antígeno core com a inflamação portal poderia ser um indício de eventual natureza auto-imune dessas lesões.

O estudo da distribuição topográfica do antígeno core conforme o padrão de lesões histológicas mostrou, no interior dos lóbulos, maior positividade em hepatócitos morfologicamente preservados. Individualmente, este achado poderia sugerir uma eficiência pelo menos parcial da necrose focal e de confluente na eliminação de antígenos virais. Por outro lado, nas regiões peri-portais, maior imunoreatividade para o antígeno core foi encontrada em hepatócitos sofrendo "necrose em sacabocados", aspecto indicativo da ineficiência da ativação dos linfócitos CD8+ na eliminação de antígenos virais nestes hepatócitos.

Estudos posteriores deverão ser direcionados à identificação destes marcadores histológicos and confluent necroses as at least partially effective in clearing viral antigens. On the opposite, at peri-portal regions, most immunostaining of HCV core antigen was detected in the hepatocytes suffering "piecemeal necrosis", which would be an important evidence for the inefficacy of CD8+ lymphocytes which directly permeate these hepatocytes on viral clearance.

Further studies should be conducted searching for these histological and molecular markers in the clinical and therapeutic context.

\section{Venâncio Avancini Ferreira Alves}

Tese apresentada à Faculdade de Medicina da Universidade de São Paulo para obtenção do Título de Livre Docente. São Paulo, SP, Brasil, 1997. 